\title{
Development of transgenic wheat (Triticum aestivum L.) expressing avidin gene conferring resistance to stored product insects
}

\author{
Heba H Abouseadaa', Gamal H Osman²,3*, Ahmed M Ramadan²,4, Sameh E Hassanein², Mohamed T Abdelsattar², \\ Yasser B Morsy², Hussien F Alameldin², ${ }^{2,5}$ Doaa K El-Ghareeb ${ }^{2,3}$, Hanan A Nour-Eldin², Reda Salem², Adel A Gad², \\ Soheir E Elkhodary', Maher M Shehata', Hala M Mahfouz ${ }^{1}$, Hala F Eissa ${ }^{2,6}$ and Ahmed Bahieldin ${ }^{4,7}$
}

\begin{abstract}
Background: Wheat is considered the most important cereal crop all over the world. The wheat weevil Sitophilus granarius is a serious insect pests in much of the wheat growing area worldwide and is responsible for significant loss of yield. Avidin proteins has been proposed to function as plant defense agents against insect pests.

Results: A synthetic avidin gene was introduced into spring wheat (Triticum aestivum L.) cv. Giza 168 using a biolistic bombardment protocol. The presence and expression of the transgene in six selected $T_{0}$ transgenic wheat lines were confirmed at the molecular level. Accumulation of avidin protein was detected in transgenic plants compared to non-transgenic plants. Avidin transgene was stably integrated, transcribed and translated as indicated by Southern blot, ELISA, and dot blot analyses, with a high level of expression in transgenic wheat seeds. However, no expression was detected in untransformed wheat seeds. Functional integrity of avidin was confirmed by insect bioassay. The results of bioassay using transgenic wheat plants challenged with wheat weevil revealed $100 \%$ mortality of the insects reared on transgenic plants after 21 days.
\end{abstract}

Conclusion: Transgenic wheat plants had improved resistance to Sitophilus granarius.

Keywords: Stored cereals insects, post harvest loss, avidin, transgenic wheat

\section{Background}

Wheat is the first most important field crop worldwide in terms of crop value and total production. Wheat production is limited by both biotic and abiotic factors [1]. Insect infestations are major factors for post harvest loss of grain quantity and quality. Preventing or at least slowing the stored product infestation is important in maintaining wheat's quality and marketable volume [2]. Insect pests contaminate stored cereals and cause damage by their feeding, producing highly toxic and carcinogenic compounds, and creation of allergens. Additionally, their metabolic products change the smell and taste of the contaminated baking products [3]. There is an urgent need to

\footnotetext{
* Correspondence: gamalhosman@yahoo.com

${ }^{2}$ Agricultural Genetic Engineering Research Institute (AGERI), Agriculture

Research Center (ARC), Giza 12619, Egypt

${ }^{3}$ Department of Biology, Faculty of Applied Sciences, Umm Al Qura

University, Makkah 21955, Saudi Arabia

Full list of author information is available at the end of the article
}

eliminate wheat insect infestation in stores, during transportation and processing, which ensures a supply of wholesome food to the consumers [4]. Chemical insecticides are being used to reduce the negative impact of the transmission of the insect infestations [5]. Complete dependency on the heavy use of chemicals has created numerous unacceptable agricultural, environmental and human health problems. Another concern is the development of resistance in target organisms [6,7]. These factors have encouraged the scientific community to discover alternative, bio-friendly, economically acceptable strategies for insect control [8-10]. Considerable progress has been made over the past two decades in manipulating genes from diverse sources and inserting them into crop plants to confer resistance to insect pests, diseases, tolerance to herbicides, drought, improved nutritional quality, increased effectiveness of bio-control agents, and a better understanding of the nature of gene action and metabolic 
pathways [11-14]. Transgenic biotechnology can be utilized as an alternative choice for protection of crops from attack by insect pests using insect growth-inhibiting proteins e.g., insect chitinase [15], cry protein [16], vip3A protein [17] and avidin protein [18]. If genes coding for these proteins are introduced into wheat with adequate and stable expression, they can provide resistance against stored product pests over several generations. Avidin is a glycoprotein that binds biotin strongly and prevents acquisition of biotin by many organisms [19]. Biotin is a cofactor needed during important carboxylation reactions. Insects have no biosynthetic pathway for biotin and thus, must obtain it from other sources. Therefore, diets containing avidin are toxic to a wide range of insects [20]. The molecular weight of avidin is about $67 \mathrm{kDa}$. The insecticidal effect of chicken avidin has been known since 1959 when it was first reported that the protein is toxic to the housefly, Musca domestica [21], this effect is due to the strong binding of avidin to biotin [22]. Due to its insecticidal properties, avidin has been expressed in a variety of agriculturally important plant species, for example, tobacco, maize and rice $[18,19]$. Avidin differs from other transgenic insecticidal toxins because it is not directly damaging to tissues, rather it merely withholds an essential nutrient from the insects [23]. The biotin binding activity of avidin is greatly destroyed by cooking, rendering the avidin harmless to humans following cooking. In the same way that cooked eggs (or precisely egg white) are not harmful to humans and are considered as a normal component of many people's diet [24].
Ninety seven percent of avidin's functional activity is lost by heat denaturation (i.e. cooking) at $95{ }^{\circ} \mathrm{C}$ for 5 min. In addition, avidin has the considerable advantage over conventional insecticides that it is not washed away during processing and continues to act as an insecticide during storage [20]. In this study, we introduced a modified avidin gene into wheat in order to protect it from stored product insects, and we investigated the insecticidal activity of transgenic wheat against wheat weevil.

\section{Methods}

\section{Insect}

Wheat weevil Sitophilus granarius were obtained from the insectary at the Agricultural Genetic Engineering Research Institute (AGERI) - ARC- Egypt.

\section{Construction of recombinant genes}

The synthetic avidin gene including Barley alpha amylase signal peptides was designed as outlined by [20]. Codon bias was checked through the codon usage table of wheat (NCBI-GenBank, http://www.kazusa.or.jp/codon). An 496 bp EcoRI fragment containing the full-length synthetic avidin (synthesized by Bioneer co., http:// eng.bioneer.com) was filled using Klenow fragment and blunt-end ligated to the previously digested and filled BamHI site of pAHC17 [25]. The 2100 bp HindIII fragment containing bar gene cassette with the ubiquitin promoter was at the HindIII site of pAHC17 (Fig. 1).

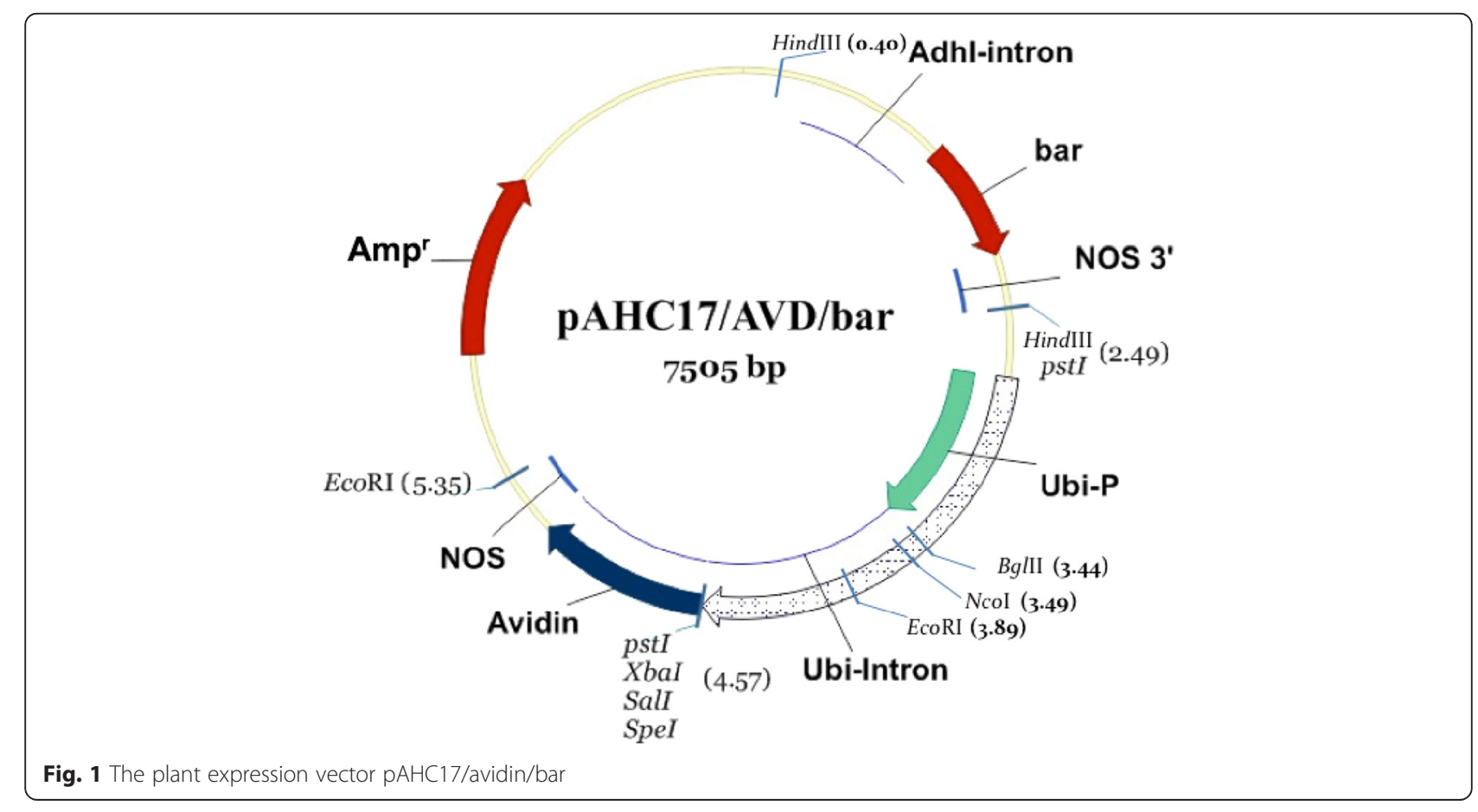




\section{Wheat transformation}

Immature embryos were isolated from field grown bread wheat (Triticum aestivum L.) cv. Giza 168(G168).Tissue culture and transformation systems were performed [26]. Primary transformants were transferred to the biocontainment facility and tested using leaf painting assay with a $0.1 \%$ aqueous solution of Basta ${ }^{\text {TM }}$ (Bayer Crop Science PVT Ltd) containing $20 \%$ glufosinate ammonium.

\section{Polymerase chain reaction (PCR)}

Genomic DNAs were extracted from putative transgenics plants, resistant to the herbicide Basta, as well as the wild type control, using the CTAB method [27]. PCR was performed by the amplification of avidin gene (496 bp) as well as for the bar gene (400 bp) using specific primers (Table 1).

The reaction conditions were optimized and mixtures (50- $\mu$ l total volume) composed of dNTPs (0.2 mM), $\mathrm{MgCl}_{2}$ (1.5 mM), 1x buffer, primer $(0.2 \mu \mathrm{M})$, DNA (100 ng), Taq DNA polymerase (2 units). Amplification was carried out in a Biometra ${ }^{\mathrm{TM}}$ PCR programmed for 40 cycles as follows: $94{ }^{\circ} \mathrm{C} / 4$ min for primary denaturation (1 cycle); $94{ }^{\circ} \mathrm{C} / 1 \mathrm{~min}$ for denaturation, $55{ }^{\circ} \mathrm{C} / 1 \mathrm{~min}$ for annealing with bar gene primers and $58{ }^{\circ} \mathrm{C} / 1.2$ min for annealing with Avidin gene primers, $72{ }^{\circ} \mathrm{C} / 2 \mathrm{~min}$ for extension (38 cycles); $72{ }^{\circ} \mathrm{C} / 8 \mathrm{~min}$ (1 cycle); $4{ }^{\circ} \mathrm{C}$ (overnight storage). Agarose (1.2\%) was used for resolving PCR products. Gene Ruler $100 \mathrm{bp}$ DNA ladder (Fermentas, USA.) was also run in the same gel. The run was performed at $80 \mathrm{~V}$ in Bio- Rad submarine $(8 \mathrm{~cm} \mathrm{X}$ $12 \mathrm{~cm}$ ) electrophoresis unit. Bands were detected on a UV-transilluminator and photographed.

\section{Southern blot analysis}

Genomic Southern blot analysis [28] was carried out using DIG High Prime DNA Labeling and Detection Starter Kit II (Roche cat. No. 11585 614 910) for the six selected $\mathrm{T}_{0}$ transgenics. Genomic Southern analysis of the six avidin transgenic plants AVD1, AVD2, AVD3, AVD4, AVD5 and AVD6. Genomic DNA of each line was digested with $\mathrm{NcoI}$ and SpeI and fragmented by $0.8 \%$ agarose gel electrophoresis. The blot was probed with a SpeI and HindIII fragment involving a maize ubi intron1, maize ubi promoter. Ubi is $2.08 \mathrm{~kb}$.

\section{RT-PCR}

Total RNA was extracted from transgenic as well as control non-transgenic plants using total RNA isolation system (Trizol reagent - Sigma-Aldrich, USA). Expression of the integrated transgene was tested on the RNA extracted from $\mathrm{T}_{1}$ plants that showed positive results after being sprayed with the Basta herbicide using a semiquantitative RT-PCR according to the protocol described by Eltayeb et al., [29]. RT-PCR was performed with RevertAid H Minus First Strand cDNA Synthesis Kit (Thermo Scientific ${ }^{\mathrm{TM}}$, cat. No. K1631) using avidin and actin reverse primers, separately. The reactions were followed with PCR reaction using GoTaq Flexi DNA polymerase (Promega, USA) identical to those used for the PCR analysis to generate an expected product size of $496 \mathrm{bp}$. was used as a house keeping gene to normalize the initial variations in sample concentration. Actin was amplified using forward primer: 5' TGA CGT GGA TAT CAG GAA GG 3' and reverse primer 5' GCT GAG TGA GGC TAG GAT GG 3' to generate expected product at196 bp, and the avidin primer was used as mentioned above. PCR conditions were: initial denaturation at $94{ }^{\circ} \mathrm{C}$ for $3 \mathrm{~min} ; 40$ cycles of $94{ }^{\circ} \mathrm{C}$ for $10 \mathrm{~s}, 58{ }^{\circ} \mathrm{C}$ for $30 \mathrm{~s}$ and $72{ }^{\circ} \mathrm{C}$ for $15 \mathrm{~s}$; elongating at $72{ }^{\circ} \mathrm{C}$ for $10 \mathrm{~min}$.

\section{ELISA and dot blot analysis}

ELISA performed with average of four replicates per samples according to the procedure of Clark et al., [30] and Dot blot analysis was performed as outlined in Gil et al., [31] to confirm the presence of the avidin protein in the grains of the $\mathrm{T}_{2}$ transgenic plants using antiavidin rabbit whole serum (Sigma, USA, Cat NO. A5170). Two $\mu \mathrm{g}$ of avidin protein (Sigma-Aldrich cat. A9275-1MG) was used as a positive control.

\section{Insects Bioassay}

An insect feeding bioassay experiment was conducted according to the method described earlier $[19,20]$ using three replicates of crushed seeds of transgenics and nontransgenic plants. Every replicate contained 100 mature insects of Sitophilus granarius for 21 days at $25-30{ }^{\circ} \mathrm{C}$. Bioassay was repeated 3 times and mortality was scored daily until death or pupation.

Table 1 Avidin and bar gene amplification primers

\begin{tabular}{llll}
\hline No & Primer Name & Primer Sequence & Amplification product Size (bp) \\
\hline 1 & bar (forward) & 5' TAC ATC GAG ACA AGC ACG GTC AAC T 3' & 400 \\
& bar (reverse) & 5' ACG TCA TGC CAG TTC CCG TG 3' & 496 \\
avidin (forward) & 5'GAA TCC ATG GCT AAC AAG CAC CTC AGC CTG 3' & \\
\hline
\end{tabular}




\section{Results}

This study aimed to introduce the synthetic avidin gene into immature embryo-derived calli of an Egyptian hexaploid bread wheat (spring wheat cv. Giza 168), and to investigate its ability to confer insecticidal effect on wheat plants via microprojectile bombardment using a eukaryotic expression vector containing the bar gene as the selectable marker. The modified avidin gene sequence that was used in our transformation experiments was synthesized according to a report [20] where the same sequence in the transformation of rice (Oryza sativa) plants was used.

\section{Molecular Analysis}

Construction of the plant expression vector pAHC17/avidin/ bar harboring the avidin gene

The plant expression vector used in this study was pAHC17/avidin/bar harboring the modified avidin gene [20] under the control of Zea mays ubiquitin promoter and bar gene under the control of CaMV 35 S promoter.

PCR was performed using specific primers of the two transgenes (bar and avidin) using DNA extracted from the $\mathrm{T}_{0}$ transgenic plants that were scored for resistance to the Basta herbicide, in order to confirm the presence of both genes in their genomic DNA. From the results reported in Fig. 2a and b, both transgenes are present in the genomic DNA of the six putative transgenic plants. Figure 2a shows the PCR product corresponding to the expected size of the partial-length bar gene amplification product $(400 \mathrm{bp})$ and Fig. 1b shows the PCR product corresponding to the expected size of the full-length avidin gene (496 bp).

\section{Southern blot analysis}

Total genomic DNA isolated from leaf tissue of plants that tested positive in the leaf painting assay with the herbicide and these that tested positive in PCR analyses of putative transgenics as well as the non-transgenic wheat cultivar Giza 168 as negative control were digested with the restriction enzyme mixture of SpeI and NcoI. The digestion products were subjected to electrophoresis followed by southern blot analyses and hybridized with the HindIII/SpeI restriction fragment $(2.08 \mathrm{~kb})$ of the pAHC17/avidin/bar plasmid, which was used as a probe to confirm the integration of pAHC17/ avidin/bar construct in the wheat genome. Figure 3 shows the hybridization patterns of the probe with genomic DNA of the six putative transgenics (AVD1, AVD2, AVD3, AVD4, AVD5 and AVD6) and the negative control (G 168). As expected, a fragment with expected size $(\sim 1 \mathrm{~kb})$ was detected from genomic DNA of the six transgenics and was completely absent from the non-transgenic wheat cultivar (G 168). Different insertion sites patterns (variable bands sizes per well) confirms that the six transgenic events were independently originated from multiple independent embryogenic calli representing different integration events. In addition, the numbers and sizes of bands indicated different copy numbers of the transgene avidin. For example AVD1 has four copies and AVD5 has two copies and AVD2 has one copy. Semi-quantitative Reverse transcriptase-polymerase chain reaction (SqRT-PCR) analysis: Expression of the integrated gene was tested on the RNA extracts of the T1 plants that showed positive results after being sprayed with the Basta herbicide. The results of avidin gene expression indicated the presence of the expected cDNA band size $496 \mathrm{bp}$ (Fig. 4). SqRT-PCR detected differential expression levels between the six transgenic lines. The transcription level of avidin in the AVD1, AVD4, AVD5 and AVD6 is shown to be relatively higher than those of AVD 2 and AVD3 lines.

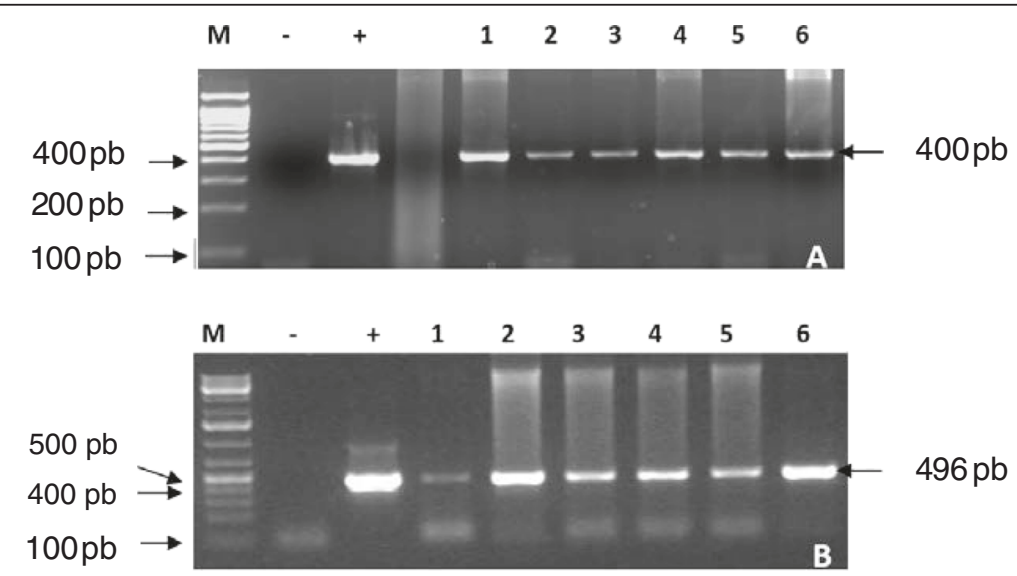

Fig. 2 PCR product of (a) partial-length bar gene and (b) full-length avidin gene of the six independent transgenic lines. (1-6; transgenic events AVD 1, AVD 2, AVD 3, AVD 4, AVD 5 and AVD 6). M; GeneRuler DNA ladder (Fermentas, USA.), +; positive control pAHC17/avidin/bar, -; negative control (non-transgenic) CV., Giza 168 

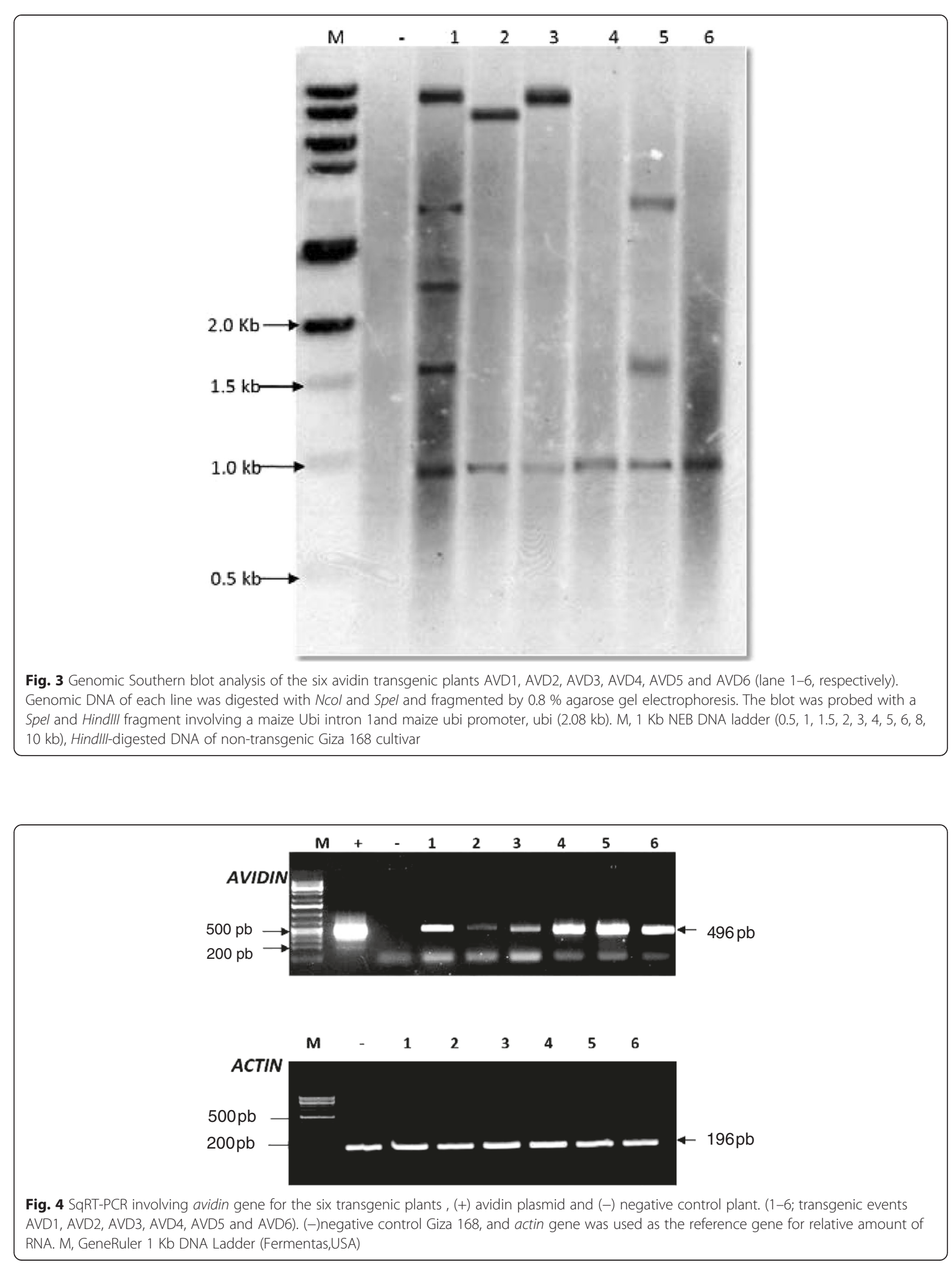


\section{Protein Analysis}

\section{Protein dot blot assay}

Avidin protein in the grains of transgenic plants, which were resistant to the Basta herbicide and Giza 168 nontransgenic cultivar was used as negative control. The six transgenic lines AVD1, AVD2, AVD3, AVD4, AVD5 and AVD6 (Fig. 5) expressed the avidin protein as well as the positive signal of the authentic avidin, while the nontransgenic cultivar, Giza 168, showed negative signal.

The ELISA was performed on the grains from $T_{2}$ plants to quantify the relative amounts of the avidin protein in each of the six transgenic events (Table 2).

AVD1, AVD5 and AVD6 had the highest absorbance values which refer to the highest avidin protein concentration (1.5 and 1.4), then AVD4 (1.2) and finally AVD2 and AVD3 giving the lowest absorbance indicating low avidin concentration (0.8).

\section{Insect Toxicity Assay}

All insects of the S. granarius died after 21 days of feeding on a diet consisting of crushed seeds of transgenic avidin wheat, whereas, none of the tested insects died when they were fed on a diet of ground seeds from nontransgenic wheat (Table 3).

Means within rows and/ or columns followed by the same letter (s) are not significantly different by Duncan's new multiple range test $(\mathrm{P}<0.05)$.

\section{Discussion}

Wheat is an important staple crop in many countries. Depending on the climatic and storage conditions, it can become infested by a wide variety of storedproduct insect pests [1]. Avidin-containing wheat and its processed products would be resistant to infestations caused by all of the species. Detection and control methods for stored product insects have to be through integrated pest management program (IPM). Major efforts involving sanitation practices, exclusion techniques, habitat modifications, fumigation, and insecticide applications are usually required to prevent damage. The conventional insect control method is mainly dependent on the intensive and extensive use of chemical pesticides, which have drawbacks such as doing harm to the ecological system, producing residual poisons to human beings and animals, and high cost. Moreover, some insects have developed resistance to some of the available insecticides $[32,33]$. Therefore, it is desirable to develop insect-resistant plants through the introduction of insect-resistant genes (e.g. avidin) through genetic transformation. In present study, synthetic avidin coding DNA was transferred to wheat plants. Avidin accumulation was detected in transgenic plants by ELISA and western dot blot. We found that avidin wheat has excellent resistance to storage insects. Bioassay experiments proved that insect mortality in the first week was about $30 \%$, in second week it was about $70 \%$ and in the third week the mortality was $100 \%$. Similar results were obtained with the red flour beetle Tribolium confusum, and flat grain beetle Cryptolestes pusillus [19]. Avidin transgenic tobacco halted growth and it caused mortality in larvae of two lepidopterans, Helicoverpa armigera and Spodoptera litura. The insects showed very poor growth over their first 8 days on a diet consisting of the leaves from transgenic plants and significant mortality were reported after 11 or 12 days and all insects were dead after 22 days [34]. In conclusion, the stable avidin transgenic wheat showed high level of resistance to the stored product insect (Sitophilus granarius). This study will hopefully decrease the loss of wheat seeds in warehouses significantly. In addition, the avidin-transgenic wheat powder can be used as a bioinsecticide. Avidin may interfere with enzymes that depend on enzyme bound biotin, such as those involved in carboxylation, decarboxylation, and transcarboxylation reactions [35]. Biotin deficiency in the blowfly, Aldrichina grahami, caused decreases in several fatty acids [36]. Presumably, a similar biochemical effect led to the stunted growth and mortality of the stored-product insects studied here. The public acceptability of avidin wheat as a food or feed is difficult to predict. Careful examination of its safety, however, is needed before consumption by humans and livestock can be considered. Kramer et al., [19] reported that at least there is no acute toxicity of avidin when feed to mice. Long-term ingestion of high levels of avidin maize may be a problem, because a biotin deficiency can decrease the growth rate of mice and affect reproduction [36,37]. However, avidin is a food protein that is consumed in the form of egg at a concentration of $>400$

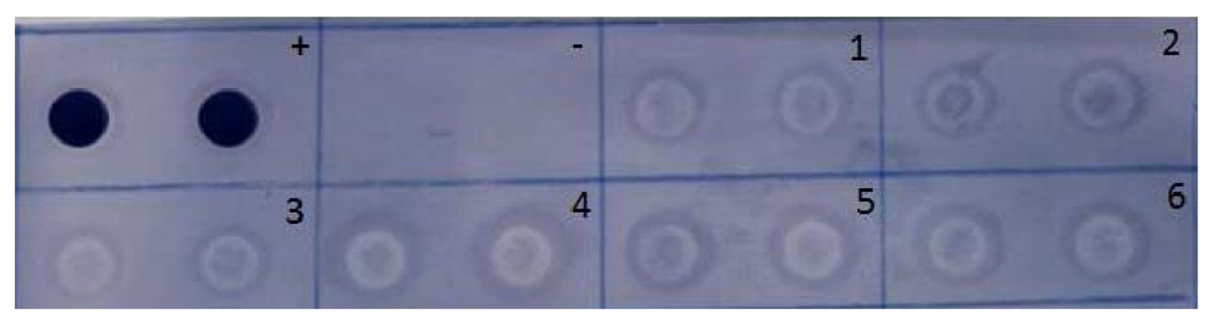

Fig. 5 Dot blot analysis of the avidin protein in the grains of the six transgenic plants and (+) positive control avidin crude protein from egg white (Sigma, A9275), (-) negative control (non-transgenic) CV., Giza 168. (1-6) AVD1, AVD2, AVD3, AVD4, AVD5 and AVD6 
Table 2 ELISA readings for the six transgenic events AVD1-AVD6 as well as the blank, negative control (-ve) and positive control (+ve) samples.

\begin{tabular}{ll}
\hline Sample & ELISA reading (absorbance) \\
\hline Blank (Extraction buffer) & 0.1 \\
Authentic avidin (+ve) & 2.0 \\
Giza 168 (-ve) & 0.4 \\
AVD1 & 1.5 \\
AVD2 & 0.8 \\
AVD3 & 0.8 \\
AVD4 & 1.2 \\
AVD5 & 1.4 \\
AVD6 & 1.4 \\
\hline
\end{tabular}

part per million (ppm) by dry weight, which is four times higher than its concentration in most of the wheat used in the present study. Moreover, avidin has an antidote (biotin), which can be used to prevent toxicity or to rescue potential victims from adverse effects. Food and feed uses of avidin wheat might involve processing that includes supplementation with the vitamins. Another method that would help to prevent potential toxicity of the avidin wheat is the heat treatment, which would denature most of the avidin as well as the avidin-biotin complex and release most of the vitamins [38-40]. Currently development of wheat expressing transgenic avidin as a food or feed grain could be considered after thorough risk assessment. In addition to its efficacy against postharvest insect pests, avidin also is effective against preharvest pests such as the beet armyworm, black cutworm, bollworm, and other species for which biotin is an essential growth factor $[41,42]$. Transferring the avidin gene to other crops will be important in determining its potential usefulness in a variety of other commercial protein production and pest control situations. Risk assessment of these transgenics can be done following the National Biosafety Committee guidelines for the most efficient avidin-

Table 3 Means for survival of Sitophilus granarius that were fed on the transgenic events and the non-transgenic cultivar crushed seeds in their diets for 21 days.

\begin{tabular}{llllll}
\hline line & 0 day & 7 days & 14 days & 21 days & Mean \\
\hline AVD1 & $100 \mathrm{a}$ & $69 \mathrm{~d}$ & $29 \mathrm{~g}$ & $0 \mathrm{~h}$ & 49.5 \\
AVD2 & $100 \mathrm{a}$ & $74 \mathrm{c}$ & $32 \mathrm{e}$ & $0 \mathrm{~h}$ & 51.6 \\
AVD3 & $100 \mathrm{a}$ & $73 \mathrm{c}$ & $32 \mathrm{e}$ & $0 \mathrm{~h}$ & 51.5 \\
AVD4 & $100 \mathrm{a}$ & $70 \mathrm{~d}$ & $30 \mathrm{fg}$ & $0 \mathrm{~h}$ & 50 \\
AVD5 & $100 \mathrm{a}$ & $69 \mathrm{~d}$ & $31 \mathrm{ef}$ & $0 \mathrm{~h}$ & 50.25 \\
AVD6 & $100 \mathrm{a}$ & $70 \mathrm{~d}$ & $31 \mathrm{ef}$ & $0 \mathrm{~h}$ & 50.25 \\
G168 & $100 \mathrm{a}$ & $100 \mathrm{a}$ & $98 \mathrm{a}$ & $91 \mathrm{~b}$ & 97.5 \\
Mean & 100 & 75.3 & 40.6 & 13.04 & \\
\hline
\end{tabular}

transgenic line. In addition, different species of stored cereals insects can be challenged with the avidin transgenic wheat grains and flour.

\section{Conclusion}

A synthetic avidin gene was introduced into spring wheat (Triticum aestivum L.) cv. Giza 168 using a biolistic bombardment protocol. Functional integrity of avidin was confirmed by insect bioassay. The results of bioassay using transgenic wheat plants challenged with wheat weevil revealed $100 \%$ mortality of the insects reared on transgenic plants after 21 days. In conclusion, the stable avidin transgenic wheat showed high level of resistance to the stored product insect (Sitophilus granarius).

This study will hopefully decrease the loss of wheat seeds in warehouses significantly.

\section{Abbreviations}

ELISA: Enzyme Linked-Immunosorbent Assay; G168: Giza 168; ppm: part per million; SqRT-PCR: Semi-quantitative Reverse transcriptase-polymerase chain reaction.

\section{Competing interests}

The authors declare that they have no competing interests.

\section{Authors' contributions}

H A Participated in Molecular Analysis and wheat transformation. GO suggesting idea, insect bioassay and writing manuscript. AR Participated in vector construction, RT-PCR and writing manuscript. S H Participated in data collection and statistical analysis. M T Participated in wheat transformation and PCR. YM Participated in isolation of genomic DNA and PCR. H AF Participated in Southern blot and statistical analysis. D E Participated in insect bioassay and western blot. H N Participated in western blot and dot blot. R S ELISA and dot blot. AG plants acclimatization. S E Dot blot and SDS. M S RT- PCR. HM SDS. H F participated in study design, Molecular analysis and writing manuscript. A B participated in study design and writing manuscript. All authors read and approved the final manuscript.

\section{Acknowledgement}

We are grateful to Prof. Dr. Subertnam Muthukrishnan (KSU- USA) for reading the manuscript and making valuable suggestions. We are also thankful to Prof. Dr. Zahir Hussien (Alberta University- Canada) for revising the manuscript.

\section{Author details}

'Department of Botany, Faculty of Science, Ain Shams University, Cairo, Egypt. ${ }^{2}$ Agricultural Genetic Engineering Research Institute (AGERI), Agriculture Research Center (ARC), Giza 12619, Egypt. ${ }^{3}$ Department of Biology, Faculty of Applied Sciences, Umm Al Qura University, Makkah 21955, Saudi Arabia. ${ }^{4}$ Department of Biological Sciences, Faculty of Science, King Abdulaziz University (KAU), Jeddah 80203, Saudi Arabia. ${ }^{5}$ Plant Soil and Microbial Sciences Department, Michigan state University, East Lansing M9, 48824, USA. ${ }^{6}$ College of Biotechnology, Misr University of Science and technology, Giza, Egypt. ${ }^{7}$ Department of Genetics, Faculty of Agriculture, Ain Shams University, Cairo, Egypt.

Received: 10 May 2015 Accepted: 7 July 2015

Published online: 22 July 2015

\section{References}

1. Bahieldin A, Mahfouz HT, Eissa HF, Saleh OM, Ramadan AM, Ahmed IA, et al. Field evaluation of transgenic wheat plants stably expressing the HVA1 gene for drought tolerance. Physiol Plantarum. 2005;123(4):421-7.

2. Campbell A, Sinha RN. Damage of wheat by feeding of some stored product beetles. J Econ Entomol. 1976;69:11-3. 
3. Mebarkia A, Rahbe Y, Guechi A, Bouras A, Makhlouf M. Susceptibility of twelve soft wheat varieties (Triticum aestivum) to Sitophilus granarius (L.) (Coleoptera Curculionidae). Agric Biol J North Am. 2010;12:571-8.

4. Niewiada A, Nawrot J, Szafranek J, Szafranek B, Synak E, Jelen H, et al. Some factors affecting egg laying of the granary weevil (Sitophilus granarius L.) J Stored Prod Res. 2005;41:544-55.

5. Osman G, Assaeedi A, Osman Y, El-Ghareeb D, Alreedy R. Purification and characterization of Bacillus thuringiensis vegetative insecticidal toxin protein(s) Lett. Appl Microbiol. 2013;57:310-6.

6. EL-Ghareeb DK, Osman GH, AF E b. Isolation, cloning, and overexpression of vip3Aa gene isolated from a local Bacillus thuringiensis. Biocont Sci Technol. 2012;22(1):11-21

7. Osman G, Already R. AssaeediA, Organji S, El-Ghareeb D, Abulreesh H. Althubiani A. S. Bioinsecticide Bacillus thuringiensis a Comprehensive Review. Egypt J Biol P Co. 2015;25(1):271-88.

8. Assaeedi A, Osman G, Abulreesh $\mathrm{H}$. The occurrence and insecticidal activity of Bacillus thuringiensis in the arid environments. AJCS. 2011;5(10):1185-90.

9. Osman G, Hussein EM, Abdallah NA. Characterization and Purification of a Chitinolytic Enzyme Active against Sesamia cretica (pink borer). Arab. J. Biotech. 2004;7:65-74.

10. Osman G, Mostafa S, Sonya H. Mohamed. Antagonistic Activities of some streomycete isolates against some phytopathogens Pak. J Biotecnol. 2007:4(1-2):65-71

11. Chen WP, Gu X, Liang GH, Chen MS, Liu DJ, Gill BS. Introduction and constitutive expression of a rice chitinase gene in bread wheat using biolistic bombardment and the bar gene as a selectable marker. Theor Appl Genet. 1998;97:1296-306.

12. Chakraborty S, Chakraborty N, Datta A. Increased nutritive value of transgenic potato by expressing a nonallergenic seed albumin gene from Amaranthus hypochondriacus. Proc Natl Acad Sci. 2000;97:3724-9.

13. Anand A, Zhou T, Trick HN, Gill BS, Bockus WW, et al. Greenhouse and field testing of transgenic wheat plants stably expressing genes for thaumatin-like protein, chitinase and glucanase against Fusarium graminearum. J Exp Bot. 2003:54:1101-11.

14. Du HY, Shen YZ, Huang ZJ. Function of the wheat TaSIP gene in enhancing drought and salt tolerance in transgenic Arabidopsis and rice. Plant Mol Bio. 2013;81:417-29.

15. Osman G, Muthukrishnan K. Cloning and Sequencing Analysis of a Chitinase Gene from Cotton Leaf Worm (Spodoptera littoralis) Noctuidae- Lepidoptera. Egypt J Genet Cytol. 2005;34:1-13.

16. Abulreesh H, Osman G, Assaeedi. A Characterization of insecticidal genes of Bacillus thuringiensis strains isolated from arid environments Ind. J microbial (short communication). (2012:52(3):500-3.

17. Osman G. Detection, cloning and bioinformatics analysis of vip1/vip2 Genes from Local Bacillus thuringiensis. Afr J Biotechnol. 2012;11(54):11678-85.

18. Elisabeth PJ, Burgess A, Malone LA, Christeller JT, Lester MT, Colleen M, et al. Avidin expressed in transgenic tobacco leaves confers resistance to two noctuid pests, Helicoverpa armigera and Spodoptera litura. Transgenic Res. 2002;11:185-98.

19. Kramer KJ, Morgan TD, Throne JE, Dowell FE, Bailey M, Howard JA. Transgenic avidin maize is resistant to storage insect pests. Nature Biotech. 2000;18:670-4.

20. Yoza K, Imamura T, Kramer KJ, Morgan TD, Nakamura S, Akiyama K, et al. Avidin expressed in transgenic rice confers resistance to the stored-product insect pests Tribolium confusum and Sitotroga cerealella. Biosci Biotechnol Biochem. 2005:69:966-71.

21. Levinson $H Z$, Bergmann ED. Vitamin deficiency in the housefly produced by antivitamins. J Insect Physiol. 1959:3:293-305.

22. Munshi A, Osman GH. Investigation on molecular phylogeny of some date palm (Phoenix dactylifra L.) cultivars by protein, RAPD and ISSR markers in Saudi Arabia. AJCS. 2010;4(1):23-28.

23. Ziegler R, Engler DL, Davis NT. Biotin-containing proteins of the insect nervous-system, a potential source of interference with immunocytochemical localization procedures. Insect Biochem Mol Biol. 1995;25:5

24. Pritchard AB, McCormick DB, Wright LD. Optical rotatory dispersion studies of the heat denaturation of avidin and the avidin-biotin complex. Biochem Bioph Res Co. 1966;25:524-8.

25. Christensen AH, Quail P. Ubiquitin promoter-based vectors for high level expression of selectable and/or screenable marker genes in monocotyledonous plant. Transgenic Res. 1996;5:213-8.
26. Sivamani E, Bahieldin A, Wraith JM, Al-Niemi T, Dyer WE, Ho TD, et al. Improved biomass productivity and water use efficiency underwater deficit conditions in transgenic wheat constitutively expressing the barley HVAlgene. Plant Sci. 2000;155:1-9.

27. Zhanguo $X$, Junping $C$. A high throughput DNA extraction method with high yield and quality. Plant Methods. 2012;8:26.

28. Southern EM. Detection of specific sequences among DNA fragments separated by gel electrophoresis. J Mol Biol. 1975;98:503-17.

29. Eltayeb AE, Yamamoto S, Habora MEE, Yin L, Tsujimoto H, Tanaka K. Transgenic potato overexpressing Arabidopsis cytosolic AtDHAR1 showed higher tolerance to herbicide, drought and salt stresses. Breeding Sci. 2011;61:1344-7610.

30. Clark MF, Lister RM, Bar-Joseph M. ELISA Techniques. In: Weissbaum A, Weissbaum H, editors. Methods for Plant Molecular Biology. San Diego, CA Academic Press; 1988. p. 507-30.

31. Gil JRN, Sbihi Y, Alvarez PA, Maache M, Larrubia M, Rojas J, et al. Development of a dot-blot system to detect gluten in food. Food Agric Immunol. 2003;15:235-42.

32. Hopkins JD, McPeake B. Household Pest and Rodent Control1986. In: Pesticides and Groundwater. U.S. Government Printing Office. Available online: http:// www.uaex.edu/farm-ranch/pestmanagement/docs/training-manuals/ AG1156.pdf. http://www.un.org/.

33. El-Menofy WH, Osman GH, Assaeedi A, Salama MS. Construction of a novel recombinant baculovirus containing Cry $1 \mathrm{Ab}$ insecticidal protein from Bacillus thuringiensis. Biol Online Proced J. 2014;4:7-16.

34. Burgess EPJ, Malone LA, Christeller JT, Lester MT, Murray C, Phillip BA, et al Avidin expressed in transgenic tobacco leaves confers resistance to two noctuid pests, H. armigera and S. litura. Transgenic Res. 2002;11:185-9.

35. Knowles JR. The mechanism of biotin-dependent enzymes. Annu Rev Biochem. 1989;58:195-221.

36. Miura K, Takaya T, Koshiba K. The effect of biotin deficiency on the biosynthesis of the fatty acids in a blowfly, Aldrichina grahami, during metamorphosis under aseptic conditions. Arch Int Physiol Biochim. 1967;75:65-76

37. Watanabe T. Dietary biotin deficiency affects reproductive function and prenatal development in hamsters. J Nutr. 1993;123:2101-8.

38. González M, Argaraña CE, Fidelio GD. Extremely high thermal stability of streptavidin and avidin upon biotin binding. Biomolec Eng. 1999;16:67-72.

39. Pei R, Wright LD. Heat stability of avidin and avidin-biotin complex and influence of ionic strength and on affinity of avidin for biotin. Proc Soc Exp Biol Med. 1964;117:341-4

40. Durance TD. Residual avidin toxicity in cooked egg white assayed with improved sensitivity. J Food Sci. 1991;56:707-9.

41. Morgan TD, Oppert B, Czapla TH, Kramer KJ. Avidin and streptavidin as insecticidal and growth inhibiting dietary proteins. Entomol Exp Appl. 1993;69:97-108.

42. Jasrapuria S, Arakane Y, Osman G, Kramer KJ, Beeman RW, Muthukrishnan S. Genes encoding proteins with peritrophin A-type chitin binding domains in Tribolium castaneum are grouped into three distinct families based on phylogeny, expression and function. Insect Biochem Mol Biol. 2010;40:214-27.

\section{Submit your next manuscript to BioMed Central and take full advantage of:}

- Convenient online submission

- Thorough peer review

- No space constraints or color figure charges

- Immediate publication on acceptance

- Inclusion in PubMed, CAS, Scopus and Google Scholar

- Research which is freely available for redistribution 